Revista Iberoamericana, Vol. LXVIII, Núm. 200, Julio-Septiembre 2002, 879-895

\title{
NORTEAMÉRICA Y SUS MUNDOS LATINOS: ONTOLOGÍAS, GLOBALIZACIÓN, DIÁSPORAS
}

\author{
POR \\ ROMÁN DE LA CAMPA \\ SUNY-Stony Brook
}

El imaginario universal suele situar la idea de América entre la utopía y la nostalgia, contornos más bien efímeros que invariablemente se turban con las líneas del deseo y la fantasía. Ya se trate de poderes coloniales, esquemas republicanos, o conquistas individuales, América ha sido un signo más bien propenso a errores cartográficos e imprecisiones mitológicas: El Dorado, El Mayflower, y Calibán quizá sean los más conocidos. Los impulsos civilizatorios del siglo Xıx buscaban una delimitación de diferencias constitutivas entre las Américas, pero sólo lograron enmarcar un juego de oposiciones implacables civilización/barbarie, anglo/latino, norte/sur, capitalismo/caudillismo— que todavía inspira fábulas de identidad y ficciones republicanas. La versión más contemporánea de ese reparto se puede observar en un léxico algo más globalizante, pero no tan lejano, que hoy se organiza en torno a las particiones orden/caos, posmodernidad/ neoliberalismo, sociedad civil/ sabrosura ingobernable. Queda por verse si las coordenadas de esta cartografía permiten ser trastocadas al borde del siglo xxI, si el afán orientador que irradia el espacio llamado América se presta a nuevos rumbos e historias inesperadas.

A la idea de América también le corresponden mitos locales, en su mayoría de cosecha decimonónica. Entre ellos, el más conocido quizá sea el de la excepcionalidad norteamericana, esa confección de un destino continental providencialmente manifiesto que todavía sostiene la identidad nacional de Estados Unidos. A esa visión de América le corresponden réplicas latinoamericanas que hoy perduran mayormente en el ámbito de la imaginación literaria. La voluntad bolivariana sondeó una unión entre las repúblicas sudamericanas del XIX sin mayor examen de las diferencias internas, entre ellas la condición política de las todavía colonias del Caribe. El pensamiento artístico de José Enrique Rodó tanteó la mejoría estética del modelo civilizatorio norteamericano, en nombre de las repúblicas del sur. Desde su exilio en Estados Unidos, José Martí acuñó el lema de batalla “Nuestra América”, inscribiendo así la cuestión racial a su crítica de las Américas, tanto del norte como del sur. Pero estas propuestas de una América no-sajona, o latina, si bien atenidas a la pluralidad nacional del XIx, auguraban algo más que recelos ante el estado sajón vecino cuya vocación americana se desplegaba como derecho natural; marcaban también la bancarrota interna del imaginario político-cultural de la clase criolla dominante en América Latina, que continúa hasta nuestros días. 
No obstante la tenacidad de estas confecciones originarias, en nombre de las cuales mucho se ha hecho y escrito, se observa hoy, en la víspera de otro siglo, una variación impensada por la cartografía de ese equívoco llamado América. Me refiero al mundo de la latinidad norteamericana, cuyas dimensiones demográficas, políticas y culturales actuales constituyen un novedoso desafío, tanto para los mitos establecidos como para el pensamiento crítico dedicado a las Américas. Se cuentan ya 32 millones de "latinos" en Estados Unidos, cifra que incluye a los nacidos allí de descendencia latinoamericana, los emigrados legalmente, y el estimado más conservador de la inmigración ilegal. A esta cantidad debe añadirse la de $\$ 300$ billones, que corresponde al mercado de consumo de productos anunciados en español que ha despertado esta población en Estados Unidos, aunque no toda ella sea de habla hispana, ni toda ella se abstenga de consumir productos anunciados en inglés, ni todos los productos anunciados en español sean consumidos por ella. El correlato político de estas cifras es imaginable. Crece también la representación de los latinos en ambos partidos políticos, al igual que la importancia que ambos partidos le otorgan al creciente voto latino. La campaña presidencial del año 2000 ya ofrece dos candidatos más o menos oficiales, el actual vicepresidente Al Gore del partido demócrata, y el gobernador de Texas, George W. Bush (hijo del ex-presidente George Bush), del partido republicano. Ambos intentan expresarse en español con cierta gracia. Es una estrategia que ya se había manifestado en ocasiones previas: Kennedy fue conocido por su coqueteo con el idioma alemán, pero Reagan, Clinton, Dole, y Bush padre, entre otros, comenzaron a regar palabras en español en medio de sus discursos en inglés. Con Gore y Bush hijo se ven por primera vez candidatos presidenciales norteamericanos que incorporan a su repertorio discursos y conferencias de prensa en español.

La denominación "latina”, hoy tan en boga para identificar la población de Estados Unidos que otros prefieren llamar "hispana”, convoca a un difuso debate que no siempre satisface. Explicar todas las razones que se dan para apoyar o negar el valor del término puede alejarnos del análisis cultural que ahora nos preocupa. De mayor interés sería explorar la dualidad ontológica que suscita la idea de una latinidad norteamericana. Me refiero a un sentimiento plural en cuanto a lenguaje, cultura y nación. No me refiero simplemente a la condición bilingüe o bicultural de la población latina de Estados Unidos. Tampoco se trata de otro capítulo del llamado crisol de las razas-ese proceso de asimilación a la vida americana de Estados Unidos-que marca la historia de sus inmigrantes europeos. Se trata de una dualidad insólita y persistente, cultivada por el nutrido cordón de capitalhumano, simbólico y financiero-entre las Américas. Esa dualidad ha configurado un modelo civilizatorio que turba las mitologías originarias, tanto del norte como del sur.

Al usar el vocablo "latino” no se puede negar su relación morfológica con el término "latinoamericano", pero importa notar que este término en sí ya trae consigo una historia de múltiples referentes, imaginarios e imprecisiones. Decir latinoamericano, más allá de sus posibles connotaciones francesas, conduce a una otredad americana que busca distinguirse primero de la tradición colonial española, luego de la gesta imperial norteamericana, y a menudo de las dos al mismo tiempo. De manera que la propia latinidad de Latinoamérica ha sido un término que se invoca en la búsqueda de diferencias entre errores cartográficos y presiones geopolíticas que incumbe a todo el ámbito hispanoamericano al igual que a Brasil. Cualquier tipo de indagación sobre la nueva latinidad en Norteamérica nos llevaría 
de lleno al espacio cultural de olas migratorias arrojadas al tránsito transnacional entre las Américas. Podrá decirse que ese nuevo uso del término latino es una imprecisión, o una impostura, pero no hay duda que responde directamente al rejuego de palabras y poderes implícito en toda la historia de gestos fundacionales sobre las Américas latinas.

En la era global, lo latino quizá aluda a un estado ontológico más generalizado, a un sentimiento de sujetos que ya no se orientan por las oscilaciones norte/sur, anglo/hispano, ciudadano/exiliado. La polisemia latina remite también al creciente espacio del marketing globalizante: el mercado de lo latino en la música popular no distingue entre latinos de Estados Unidos, latinoamericanos, y españoles. Jennifer López, Gloria Estefan, Mark Anthony, Ricky Martin, Enrique Iglesias, Antonio Banderas y hasta Julio Iglesias, se identifican alegremente con el rótulo impreciso de latinos en Estados Unidos. Unos comenzaron cantando en inglés, otros en español, todos han pluralizado sus idiomas performativos. El show de Cristina y los noticieros en español emitidos en Telemundo y Univisión también se dirigen a lo latino sin distinguir entre latinoamericano y latino en Estados Unidos, y mucho menos entre las nacionalidades o exilios que ambos pueden representar. Pero esto va más allá de la lengua o la cultura. Se trata de confeccionar un performance gobernado por las técnicas y estéticas del crossover global.

Lo que más importa observar aquí es que la nueva latinidad, escena que quizá incluya la globalización de la música salsa, podría valer de tropo a las pulsaciones del capitalismo global. La autogestión capitalista hoy se desdobla incorporando formas culturales y mitos originarios en una nueva dinámica de mercado que no separa claramente la esfera económica de la cultural. La presencia de Hollywood se torna omnipresente en todos los renglones de la industria de servicios contemporánea: política, videos, restaurantes, marcas de ropa, relatos étnicos, es decir, todas las tramas posibles se tornan vendibles. Surge un modo más artístico de confeccionar el horizonte del consumo, esa relación tan estrecha entre el deseo y la ilusión. De manera que el sujeto arriba a la frontera de la auto-confección ontológica como si las posibilidades de pluralizarse escondieran en sí el secreto de una nueva utopía, quizá la única restante en una época tan incrédula. Ser muchas cosas, cambiar de identidades, hacer múltiples crossovers, lograr pensarse según el deseo y la ocasión como si la mutación metafísica se hiciera posible a través de los productos a su alcance. Pero hay algo precipitado y quizá hasta ufano en esta recapitulación sobre el contexto global de la latinidad norteamericana. El tema exige otras complicaciones.

La presencia de latinos o hispanos en Estados Unidos encierra una historia de siglos. Aunque podría trazarse desde finales del dieciocho, se suele citar inmediatamente la presencia cubana y puertorriqueña en la costa este desde finales del siglo diecinueve, momento migratorio que correspondía a la condición colonial tardía del Caribe hispano, y a las subsecuentes guerras de independencia contra España. Es una historia conocida, particularmente por la importancia de escritores como Hostos, Martí, y Betances, al igual que por las querellas internacionales que produjo la guerra de 1898 en todo el Caribe de habla hispana. Hay, sin embargo, otra historia de mediados del diecinueve, menos atendida pero quizá más engorrosa, que apenas se comienza a contar. Es la historia del territorio que hoy ocupan casi todos los estados del oeste y suroeste de Estados Unidos, que México cede con el tratado Guadalupe-Hidalgo de 1848. Hay por lo tanto medio siglo de vastas y nutridas experiencias mexicano-norteamericanas en el diecinueve, antes de que España se retire 
finalmente de sus posesiones americanas en 1898. ¿Cómo negociaron la identidad cultural los mexicanos que una mañana despertaron con otra nacionalidad? ¿Cómo configurarlos en el relato transoceánico del Mayflower, o en el ritual culinario de Thanksgiving, que la nación norteamericana ha cultivado durante más de 200 años? Lo mismo podría preguntarse de los españoles — nativos o criollos_ que residían en territorios recién incorporados por México unas dos décadas antes con motivo de la independencia. Españoles, mexicanos, norteamericanos — poco se ha escrito sobre la multiplicidad cultural y nacional hispana del siglo XIX dentro de la nueva nación norteamericana. Menos se habla aún de las culturas indígenas desplazadas de sus territorios y fundamentalmente desentendidas de todas estas configuraciones nacionales.

La latinidad norteamericana se hace sentir algo más a mediados del siglo veinte. Emerge de las olas migratorias de mano de obra que proviene de países americanos cuyo espacio nacional quedó incierto desde siempre, irresolución que hoy si acaso cobra relieve y relevancia en el ámbito posnacional de diásporas actuales. Lo reprimido tiende a retornar, en este caso en la forma del nuyorican (puertorriqueño neoyorquino) el chicano (mexicoamericano), luego en su manifestación cubana — el primer exilio, las olas del Mariel y los balseros-, y luego de muchos otros países. Los chicanos y nuyorican corresponden a lo que podría llamarse la latinidad histórica, que el cine y el teatro (West Side Story y Zoot Suit, respectivamente) recogen cuando estas migraciones de trabajadores desempleados o subempleados entran en el imaginario nacional en tanto pandillas de delincuentes en Nueva York y Los Angeles. Eran mucho más, como puede verse en la descripción de los pachucos que ofrece Octavio Paz en su Laberinto de la Soledad. La voluntad de vida que irradia el estilo chicano a finales de los 40 sacude al conocido escritor mexicano: se le obceca la identidad nacional ante la imagen de esos jóvenes. Muy lejos también del simple pandillero peligroso es el retrato del sujeto nuyorican que provee la poesía de Miguel Algarín, fundador de “NuyoRican Poet’s Café” en la ciudad de Nueva York. Allí se dibuja un personaje futurista, una síntesis de agilidad y creatividad digna de artistas fronterizos.

Estas poblaciones de primera mitad del siglo XX acuden irremediablemente a las grandes ciudades industriales norteamericanas, ubicadas en el famoso cordón de acero. Las masas de trabajadores de la nación negra del sur de Estados Unidos responden a las mismas presiones laborales. Los barrios de Harlem y Loisaida (Lower East Side) recogen la vitalidad artística de esta historia en Nueva York; Motown, capital de la música negra, brota del Detroit de la industria automovilística; los juegos infantiles de La casa en la calle Mango, de la conocida escritora Sandra Cisneros, figuran toda una complicada historia chicana en Chicago desde hace más de medio siglo. Los nuyorican y los chicanos de los cincuenta no eran hispanos ni latinos todavía, eran poblaciones olvidadas y desdeñadas por ambos lados de su dualidad cultural. Eran muestras tempranas de una ontología doblemente negativa: ni una cosa, ni la otra; indeseables en Puerto Rico o México y, por supuesto, en Estados Unidos. En las capitales del pensamiento político y literario latinoamericano de vanguardia, tampoco comparecían. Los conocidos premios literarios de la institución cubana Casa de las Américas, por ejemplo, no incorporaron a la literatura chicana hasta comienzos de los ochenta; la nuyorican permaneció dentro del corpus puertorriqueño. Estas eran, sin embargo, manifestaciones culturales de conocido arraigo desde mucho antes. Eran poblaciones cuya articulación de estilo asumía esa dualidad negativa que tanto turbó a 
Octavio Paz: esa relación oblicua ante dos nacionalidades, dos lenguas y dos culturas, que rompía tan tajantemente con el histórico binarismo latino/anglo americano de la nación del XIX. Podría argüirse que esa voluntad de vida grabada en la negación ontológica, con el tiempo, encuentra un punto en el mapa de formas reconocibles por la filosofía contemporánea. Como la deconstrucción de relatos modernos, es ese no escoger entre dos opciones ineludibles, que si bien nunca llega a designar una alternativa concreta, al menos permite aprender a vivir de-significando cuidadosamente lo conocido.

Cuba entra en esta historia de la latinidad norteamericana después de 1959. Era también una ola migratoria, pero en este caso no se trataba de trabajadores desempleados sino de una clase pudiente que salía de su país en masa, y que fue muy bien recibida en Estados Unidos. El éxito económico de este flujo de profesionales cubanos, muchos de ellos hijos de españoles, transformó la ciudad de Miami. De suburbio provinciano, poblado mayormente por neoyorquinos aclimatados al sur de la Florida, y turistas que visitaban sus balnearios aledaños, Miami pasó a los diseños cartográficos de la pequeña Habana a partir de los sesenta. Algunos observadores han propuesto encajar la inmigración cubana anterior al 59 en esta historia, por la presencia de músicos como Desi Arnaz (Ricky Ricardo), y otros mucho más importantes que formaron parte de las grandes orquestas que Oscar Hijuelos tanto añora en su novela Mambo Kings. Pero esa migración, de mucho menor escala, pertenece a la historia neoyorquina, sobre todo la musical, y no es sólo cubana. Corresponde a otra etapa que no se debe confundir con la que surge después del 59. Eran los cuarenta y principios de los cincuenta, primera época del mambo en los salones de baile neoyorquinos que también abrió el paso a la música puertorriqueña y a la samba brasileña. La vida de Arnaz puede ser el episodio más fácilmente recordado — quizá por las contradicciones que reprime - dentro de este esquema de latinidad incipiente, pero la de Carmen Miranda, nacida en Portugal, emigrada a Brasil y luego consagrada en Estados Unidos como estrella de sambas brasileñas, remite a una historia mucho más compleja e interesante. Nacía en aquel entonces la televisión norteamericana, la cual todavía impedía la representación directa de artistas negros, pero abría sus puertas a ritmos exóticos como la música cubana y brasileña. Como en el béisbol del momento, se prohibía la actuación del cantante o jugador negro pero se integraban intérpretes y representantes de una otredad substituta, sobre todo la del latino. Poco después, con Elvis, surge en la escena cultural no sólo la transgresión de un rockero proletario predispuesto a pulsaciones pélvicas, sino también una actuación más localizada de la tradición musical afroamericana que ya no depende solamente de intérpretes e intermediarios latinos.

Con el tiempo, ya en los noventa, Miami pasará a ser una capital latina que complica tanto el sentido latinoamericano como norteamericano de la palabra, pero el recuento de los sesenta motiva otras observaciones. Es difícil, y quizá aventurado, hacer comparaciones muy directas entre la ola migratoria cubana que parte hacia Estados Unidos del 59 al 65, y las poblaciones chicanas y nuyoriqueñas descritas anteriormente. El éxito económico de esa cubanidad en Miami y otras partes exige un análisis cuidadoso que permita distinguir, sin prejuicios, la experiencia de grupos que provenían de clases sociales y circunstancias migratorias muy distintas. Se olvida a veces que las clases pudientes puertorriqueñas y mexicanas han permanecido en sus respectivos países. Se olvida también que la ola migratoria inicial cubana constituía una carta valiosa para Estados Unidos en medio de la 
Guerra Fría, mientras que los dos otros grupos remitían a una historia más turbia de relaciones e intervenciones en la cartografía nacional de México y Puerto Rico. No debe sorprender pues que la cubanidad miamense esquive la clasificación latina o hispana e insista en un exilio cubano sin más, ni que se desentienda de la dualidad negativa de esos otros grupos latinos cuya experiencia en Estados Unidos era mucho más antigua y enrevesada. Entre el exilio cubano de aquella época y Washington no había un sentido de rechazo, sino al contrario, un profundo agradecimiento por la acogida de puertas abiertas y por la promesa implícita de que el regreso triunfal a la isla tomada por un gobierno comunista, estaba más o menos garantizado. Entretanto, en Miami surgía una ciudad orientada fundamentalmente por la nostalgia nacional y el apego al trabajo. Pero podría observarse que también habían recelos y sentimientos encontrados en cuanto a la nueva coyuntura existencial. Preservar la memoria del país abandonado también exigía un acto de negación, o al menos de represión, de las transformaciones que en él surgían. Cuba quedaba congelada en el recuerdo. Con el tiempo, la longevidad de la revolución introduce la duda, o sospecha, en cuanto a las posibilidades del regreso y hasta la voluntad de lograrlo. Pero la reflexión más profunda sobre el verdadero espacio nacional del exilio - Estados Unidos - no había comenzado todavía. Comienza a surgir, quizá, con las migraciones posteriores del Mariel y los balseros, al igual que con el cambio de política norteamericana en torno a la inmigración cubana.

La cartografía aquí esbozada hasta mediados de los sesenta presupone, por tanto, dos agrupaciones totalmente diferentes de latinidad norteamericana: una de descendencia mexicana y puertorriqueña instalada en las costas este y oeste, la otra de origen cubano al sur. Esto es, claro está, una mera simplificación para establecer un marco comparativo en este momento histórico, ya que las migraciones mexicanas y puertorriqueñas exigen su propia historia de diferencias. Además, se trata de un momento que, por otra parte, reclamaría ubicar la importante gesta de negros y judíos norteamericanos en la contienda por los derechos civiles, al igual que la experiencia migratoria asiática. En todo caso, la historia de la cubanidad en Estados Unidos se complica significativamente con dos olas migratorias posteriores, cuya composición racial y social eran muy distintas de la primera. Podría decirse que hay otra ola migratoria que va del 65 al 73, sin embargo, aunque numerosa, se integra fácilmente a la primera; carece del impacto dramático de las dos subsiguientes. ${ }^{1} \mathrm{El}$ éxodo por el puerto Mariel, en 1980, y el constante flujo de balseros durante los 90 transforma radicalmente el relato inicial del exilio cubano, y en gran medida el de la Cuba revolucionaria también. Se triplica el número de cubanos en Estados Unidos, incorporando a muchos nacidos y crecidos durante el régimen revolucionario. Se comienza a pluralizar la ontología cubana en una simultaneidad que en cierto modo trastorna el compás ideológico inicial: se recubaniza Miami con la llegada de cientos de miles de cubanos cuya cultura remite a todo un conjunto de experiencias revolucionarias o al menos postsocialistas; surge una generación de cubano-americanos nacidos en Estados Unidos que nunca han conocido el suelo natal; se produce un encuentro de todo lo anterior con otros latinos, puesto que a

\footnotetext{
${ }^{1}$ Para un acercamiento estadístico a la demografía cubana en el exilio, ver el trabajo de Lisandro Pérez, "De Nueva York a Miami”.
} 
Miami comienzan a llegar otras olas de inmigrantes latinoamericanos y de latinos de otras partes de Norteamérica.

El sueño del regreso a La Habana perdida en el 59 comienza a ceder ante una configuración demográfica más joven y de mayor variedad racial, con otra formación ideológica, y con intereses económicos y políticos algo diferentes. De un espacio reservado para el exilio político de elites profesionales, Miami se convierte en una capital de olas migratorias de trabajadores postsocialistas cuya relación con el país natal es más reciente y dinámica. Si bien se palpa en estas poblaciones el deseo de libertades políticas y económicas que no se permiten en la isla, también se observa el deseo del derecho a viajar libremente a Cuba que el Miami de la primera ola migratoria no ha querido permitir. Por otra parte, Cuba, hasta hace no mucho conocida como capital simbólica del tercer mundo, no puede ya disimular los éxodos en masa a Estados Unidos: cientos de miles de trabajadores formados por la revolución, muchos de los cuales sólo habían conocido el imaginario revolucionario desde su nacimiento, arriesgan la vida para abandonar el país. Otra insoslayable ironía se da cuando muchos de estos emigrados comienzan a regresar de visita a su país inmediatamente, acompañados del gran privilegio que ahora le otorga el régimen revolucionario a la posesión de divisas extranjeras.

Sería algo anacrónico, o caprichoso, confeccionar hoy historias de la cubanidad miamense sin tomar en cuenta estos cambios insólitos. Pienso particularmente en el conocido relato de Gustavo Pérez Firmat, Life on the Hyphen, tan nostálgico por el Miami anterior al Mariel. La identidad nacional, y de clase, de ese primer exilio es férrea, pero la cubanidad miamense ha sido profundamente transformada, y la latinidad miamense ha dejado de ser una historia exclusivamente cubana, si se toman en cuenta las otras olas migratorias de origen latinoamericano y caribeño que allí llegaron durante los 80 y 90 . Al sur de la Florida han emigrado miles de nicaragüenses y otros centroamericanos desplazados por los veinte años más recientes de guerrilla y contraguerrilla en esa área. A ello habría que añadir la creciente migración de sudamericanos, entre ellos brasileños, colombianos y argentinos. El surgimiento de Disneyworld, al centro de la Florida, también cuenta con decenas de miles de trabajadores latinoamericanos y latinos nacidos en Estados Unidos. Además, siempre hay en la Florida todo un ejército de los llamados trabajadores migratorios que recogen productos cítricos, aun si suelen pasar desapercibidos por el discurso político oficial. Pero esta complejidad demográfica en la Florida sigue siendo un mero preludio de otros cambios igualmente profundos. La geografía histórica de los chicanos y nuyoricans también observa enormes transformaciones desde los sesenta, y no sólo en las costas norteamericanas. Para los 90, Los Angeles y Nueva York comprenden constelaciones de millones de latinos de múltiples orígenes nacionales, incluyendo los nacidos allí. En el suroeste y medio oeste del país, Denver, Chicago, San Antonio y otras grandes ciudades se suman al mundo de las capitales latinas de Estados Unidos. El cordón hemisférico de latinidad ha dejado de reconocer fronteras nacionales, lingüísticas, o culturales.

Podría dársele un cierre provisorio a la ruta migratoria que he intentado trazar aquí, observando que ese mundo de 32 millones de latinos actuales en Norteamérica — sus capitales, las industrias políticas y financieras que suscitan, la globalización de imágenes televisivas que emiten, las muy diversas historias que los preceden, $\mathrm{y}$, por supuesto, los nutridos imaginarios que los acompañan- constituye una constelación civilizatoria 
profundamente difícil de narrar y categorizar. Es en gran medida un capítulo desconocido en la historia de las Américas que de pronto se destapa y que no responde directamente a esquemas nacionales. Pero es también un temario que reclama estudio, debate, y sobre todo atención internacional. En lo que queda de este ensayo intentaré acercarme un poco más a los aspectos de este temario que me parecen particularmente relevantes, es decir, la constelación de nuevas olas migratorias transnacionales, nuevas capitales continentales, e imaginarios de ontología plural. Se trata también de un esbozo de quiebres y resquicios que atañen al pensamiento cultural contemporáneo y aún más particularmente a las disciplinas que lo canalizan, sobre todo las humanidades y las ciencias sociales letradas.

A partir de los 90, Estados Unidos descubre casi súbitamente la realidad multinacional de las Américas en el suelo nacional: americanos otros — procedentes o descendientes de migraciones latinoamericanas — que siguen nutriendo su procedencia cultural aun después que ésta se duplica o pluraliza con la vida norteamericana. Esa latinidad trae consigo múltiples niveles de hibridez y superposición de elementos —históricos, lingüísticos, raciales - que complican las dos bases fundamentales del mito norteamericano del crisol de las razas: el monolingüismo angloparlante, y el binarismo racial blanco/negro. El crisol de las razas siempre ha implicado que los diversos grupos culturales, lingüísticos, o étnicos, de descendencia europea, eran alegremente asimilados a la unión nacional norteamericana. La matriz racial de este imaginario nunca se articulaba claramente, pero ahí estaba, en un estado relacional bastante confuso con otras categorías cercanas, como la etnicidad. Los irlandeses, los italianos y los judíos, por ejemplo, fueron categorizados como razas no necesariamente blancas por un tiempo en Estados Unidos. Pero luego, tras un proceso de compenetración cultural y lingüística, obtuvieron entrada dentro de la agrupación de blanca en tanto variación étnica. Lo racial pasaba a los contornos de lo étnico antes de confirmarse plenamente americano.

Las poblaciones negra y amerindia, y en cierto modo la asiática, nunca se han registrado en ese crisol, lo cual implica que su pertenencia nacional es sometida a pruebas constantes, a pesar de su larga historia en el territorio americano. Permanecen constituidos como razas cuya entrada al ancho embudo étnico queda trabada. Pero las masas latinas desmontan ese concepto del crisol, ya que comprenden una población de múltiples razas, culturas y lenguajes que remite a una complejidad civilizatoria profundamente americana que nunca ha formado parte del discurso nacional de Estados Unidos. No quiero decir con esto que el mestizaje o la hibridez de América Latina sea un discurso sin contradicciones o sin sus propias formas de racismo. Pero se puede observar que esa latinidad masiva introduce una vivencia americana imprevista por el compás étnico, racial, y lingüístico del imaginario nacional norteamericano. Las categorías formales del censo remiten a esta contradicción: los latinos no son ni etnia ni raza, corresponden a una agrupación que desmonta el crisol, tornándolo imposible para la clasificación futura de la nación.

Importa también sondear el impacto de la latinidad norteamericana en el imaginario latinoamericano. Cada nación de América Latina siempre ha imaginado su participación en la patria grande latinoamericana a su modo, aún si muchos ciudadanos nunca tienen un contacto directo con otras nacionalidades del área, o aun si lo hacen negativamente, es decir, nutriendo una constante rivalidad o sentimiento de superioridad hacia países vecinos. América Latina es, a veces, una patria hispanohablante, a veces un espacio étnico, otras 
veces un reclamo regional, y luego una combinación imprecisa de todo ello. Claro que Brasil siempre se ha sentido algo soslayada por esta constelación latinoamericana que suele ser más bien hispanoamericana, puesto que los imaginarios, y sus textos, suelen partir de idiomas concretos. No conozco un brasileño que no entienda muy bien el español — de hecho muchos hablan portuñol- mientras que pocos hispanoamericanos entienden un diálogo en portugués. El caribe africano y la América indígena también comprenden capítulos difíciles en esa representación de lo latinoamericano. Claro está, el cono sur tiene su propia idea del ser latinoamericano, y los países andinos la suya, pero toda esta raigambre de diferencias se desvanece en el imaginario paradigmático de lo latinoamericano; todas estas zonas y regiones permanecen más o menos sujetos a una participación transhistórica en ese relato colectivo de lo latinoamericano que se nutre desde la localidad nacional.

Se debe observar, sin embargo, que muchos latinoamericanos creen descubrir a América Latina en Estados Unidos. Esto puede parecer irónico, pero se entiende fácilmente, ya que es muy posible encontrar una representación más amplia de latinoamericanos en Nueva York, Miami, Chicago o Los Angeles que en muchas capitales latinoamericanas. No pretendo afirmar que se pueda ser más latinoamericano en Estados Unidos que en América Latina, sino que la inmensa presencia de latinos en Estados Unidos ha complicado considerablemente ese imaginario latinoamericano. Esto se observa precisamente cuando regresan muchos latinos a sus países de origen, ya sea de visita, de vuelta, o en tránsito oscilante. De pronto descubren que han perdido cierta especificidad: gestos, costumbres, instintos, o hasta el acento nacional. Esta experiencia no corresponde simplemente al proceso de asimilación a la cultura norteamericana: se recogen allí dejes de otras partes de América, y se participa en el nuevo vecindario de la nutrida convivencia latinoamericana que se hace posible en las capitales latinas de Estados Unidos. Una de las características más contradictorias de la latinidad norteamericana quizá sea esa posibilidad de sentirse otro dentro de dos lenguas y culturas, lo cual incluye, en muchos casos, una forma distinta del sentirse latinoamericano.

¿Cómo acoplar las distintas formas de imaginar a las Américas? Se pensaba que la idea de la diáspora sólo correspondía a Puerto Rico, cuya población quedó dividida entre naciones, lenguas y formas de gobierno desde comienzos de siglo. Claro que la historia de la migración mexicana, si se conociera mejor, o fuera menos reprimida, daría otra muestra de gran dimensión demográfica y complejidad histórica. En todo caso, hoy se puede añadir a Cuba, y se podría postular que la República Dominicana, Colombia y algunos países centroamericanos remiten también a una cultura nacional que no puede ignorar sus respectivos otros en la diáspora. Obviamente, surge inmediatamente la duda de si se puede distinguir entre la cultura nacional producida, articulada, o transmitida dentro o fuera de cada nación, sin caer en esquemas reductivos entre lo autóctono y lo foráneo. Además, ¿qué diálogo será posible entre el influyente pensamiento norteamericano, escrito en inglés, sobre la transnacionalidad americana, y el discurso nacional latinoamericano que se articula mayormente en español? ¿Y cómo ubicar la latinidad fronteriza de intermedio? No hay duda que el mercado global de imágenes y discursos profesionales exige deslindes. En sus repliegues de silencios y posibilidades quizá se encuentre una de las aporías principales de la filosofía actual. La crítica posmoderna al igual que la poscolonial, suele concebir la diáspora en un sentido estrictamente lúdico, o hasta triunfal, de exploraciones teóricas. 
Hay, sin embargo, mucho más en juego. Las divisas que envían las poblaciones latinas norteamericanas a sus países de origen han llegado a ser, en varios casos, el primer renglón de la economía nacional. Por otra parte, en La Habana, San Juan, Caracas, Bogotá, Guayaquil, Santo Domingo, Ciudad México y otras urbes latinoamericanas, hay un canje de capital y esperanzas tanto o más atento al intercambio de las capitales latinas norteamericanas que a la participación en la vida nacional. Se fractura la nación interna de muchos estados americanos. Los relatos decimonónicos ya no encubren sus grietas como antes. El mundo indígena pide, y a veces exige, una redefinición multinacional del concepto de estado, los tratados de libre comercio forjan nuevas alianzas regionales, se desdibujan las coyunturas que sostienen la vieja cartografía en las Américas, y la televisión redefine las identidades globales. Estos quiebres están, en casi todos los sentidos, más allá del alcance de la nostalgia de los viejos nacionalismos, al igual que de la mera celebración "posmoderna” de la condición diaspórica.

Importa acentuar también que se ha despertado una profunda contradicción interna entre las clases dominantes norteamericanas en cuanto al creciente uso del idioma español que hoy se observa en Estados Unidos. Es una profunda causa de alarma para la clase cultural, que atisba con cierto horror el despliegue de una segunda lengua nacional, puesto que arriesga un aspecto fundamental del ser "americano", en su sentido norteamericano histórico. Se han dictado nuevas leyes en la última década prohibiendo el uso del español entre trabajadores, en las escuelas, y en lugares de servicio público; también se ha montado toda una campaña en contra de la educación bilingüe. Pero la clase comercial ha tomado un camino opuesto al descubrir las posibilidades de un mercado global que entremezcla la novedad de otra lengua y otra cultura dentro de la nación. Este nuevo horizonte le permite anunciar y crear nuevos productos, imágenes, y en muchos sentidos, nuevas formas culturales que pasan ya de los 300 billones en consumo anual. Irónicamente, este nuevo mercado norteamericano ha contribuido a que se expanda, y en algunos casos mejore, el español de ese mundo latino. La confección de productos es exigente, requiere modelos de cuerpo y también de voces y locutores que manejan el idioma con gran soltura. El comercio masmediático se vuelve así escuela seductora, tanto para los que quieren aprender español como segunda lengua, como para quienes lo quieren cultivar un poco más, ya que el bilingüismo atrae interferencia verbal. Es una de las grandes contradicciones del capitalismo, puesto que conlleva la pluralización de la identidad de la américa anglosajona. Nótese que este nuevo mercado también tiene implicaciones para España, puesto que sus inversiones en las Américas, incluyendo la del norte, ahora encuentran un público creciente de gran alcance económico en el nuevo mercado de habla hispana. Podría decirse que el mundo latino se globaliza en torno al comercio en español a través de las Américas, aunque se trata de una esfera cultural amplia que no es reducible al habla.

Otro elemento importante de esta nueva esfera cultural tiene que ver con el cuerpo. Es consabido que la cultura siempre ha gobernado los cuerpos. Los bailes, la forma de vestir, comer, bailar, caminar, la sexualidad, en fin toda la producción del sujeto está inscrita en las formaciones discursivas ancladas en cada cultura. Se podría postular, por ejemplo, que no es sino con la globalización de la salsa que Norteamérica descubre las dimensiones estéticas de ciertas partes del cuerpo que siempre fueron negadas a esa cultura. Me refiero en particular a esa zona que configura el culo, o nalgatorio, como lo llama García Márquez. 
La cultura norteamericana, en su sentido puritano reprimido, borraba esa parte del cuerpo, o la delegaba exclusivamente a la categoría de locus excremental. Esto se observa particularmente en el lenguaje, sobre todo en los insultos. Hay todo un vocabulario de oprobios centrados en esa parte del cuerpo anglosajón. Decirle "kiss my ass” al prójimo, por ejemplo, es un gran ultraje en inglés, mientras que "bésame el culo" conduce a otros matices en español. Si bien con el rock ya se transgredía un poco esa noción de cuerpos tiesos, se convocaba exclusivamente un movimiento vertical de la pelvis, sin convocar a una mutación simultánea de las caderas. La represión corporal puritana comienza a soltarse algo más con la onda disco de los setenta, la cual ya incluía muchos instrumentos de percusión latina, y la idea de bailar era una toma de postura autorreferencial, tanto para verse uno mismo como para ser visto. No es hasta la globalización de la salsa, sin embargo, que se sitúa esa parte del cuerpo bajo otra luz. Se incorpora el meneo como gesto de la cultura nacional, y se despierta el interés por el culo en los jeans y el diseño comercial en general. Nótese que no se trata de reducir el tema a una discusión de causas, préstamos, o fuentes musicales integradas por la salsa, digamos el mambo, la rumba, o el merengue. La globalización de la salsa es un fenómeno que incorpora muchos sonidos afrocaribeños en pos de una nueva industria cultural transnacional, encargada de la confección de imágenes, sonidos, y cuerpos. El diseño ontológico de hoy requiere nuevas herramientas de estudio: invoca el consumo como frontera cultural, turbando el modo en que se entiende y se siente el cuerpo.

Para el pensamiento crítico, esta frontera exigiría una aproximación más capaz de acercarse a la posmodernidad de experiencias cotidianas que de discursos teóricos. En su conocido libro Consumidores y ciudadanos, el antropólogo Néstor García Canclini se pregunta qué función cumplen los discursos teóricos que se ocupan no sólo de homogeneizar sino de trabajar simplificadamente con las diferencias, mientras las comunicaciones electrónicas, las migraciones y la globalización de los mercados complican más que en cualquier otro tiempo la coexistencia entre los pueblos. Queda por verse cuál fuerza es más radical: las teorías del desmonte posmoderno o la privatización neoliberal de los espacios públicos, la cual incluye la institución universitaria. En todo caso hay síntomas: el mundo académico se observa al borde de su propio anacronismo; ensaya, con gran cautela y ambigüedad, múltiples redefiniciones disciplinarias. Un buen ejemplo sería el debate sobre la formación de nuevos programas de estudios culturales que intentan integrar la videocultura a la formación universitaria y al quehacer de la investigación crítica. Lo mismo ocurre con el surgimiento de estudios étnicos, estudios de la mujer, estudios de las sexualidades, y otras manifestaciones de la cultura contemporánea. Algunos textos recientes de Harold Bloom y Richard Rorty proveen una queja nostálgica ante estos cambios tan contradictorios para el aparato universitario norteamericano. Se trata de una peligrosa encrucijada para la intelectualidad académica, tanto las humanidades como las ciencias sociales: cede la especificidad de los objetos de estudio establecidos al mismo tiempo que surge un horizonte cultural que exige nuevas claves para abarcar la virtualidad autorreferencial y las tecnologías visuales.

En este contexto de nuevas fronteras intelectuales, entre las cuales se encuentra el pensamiento poscolonial, cobra un interés especial la relectura de Franz Fanon, Fernando Ortiz, C. L. R. James, Edward Glissant y otros escritores de la aun reciente historia colonial 
americana, específicamente por tratarse de autores cuya obra nos lleva a la red de disyunciones que confluyen en el Caribe durante la segunda mitad del siglo veinte: colonialismos, modernizaciones, revoluciones, y otras pulsaciones asincrónicas que vinculan a las Américas, África, Asia y Europa. Lo mismo debe decirse del pensamiento feminista, ya no sólo del Caribe sino de las Américas en general. No hay duda que el boom de escritura latina actual corresponde a una importante manifestación de escritoras. Éstos son marcos particularmente fructuosos para estudiar la latinidad, la cual proviene en gran medida de resquicios disciplinarios y geopolíticos, es decir, a todo un radio de cruces entre tradiciones lingüísticas y culturales tanto hispanas como norteamericanas. La literatura latinoamericana, por ejemplo, particularmente la narrativa, forma parte esencial de un nuevo código mundial canonizado por las traducciones a la lingua franca de la comunidad global, es decir, a un inglés cada vez más transnacionalizado que responde menos al concepto de lengua nacional que al de segunda lengua mundial. Un ejemplo de ello sería el valor de cambio extraordinario que obtiene el realismo mágico en la literatura poscolonial escrita en inglés, particularmente en la obra de Salman Rushdie, o en el cine más contemporáneo de Hollywood. Las literaturas chicana, nuyorican y de otros latinos o latinoamericanos en Estados Unidos también cobran relieve en este contexto de múltiples códigos lingüísticos, culturales e históricos; al igual que la creciente yuxtaposición de lo latino norteamericano con lo latinoamericano en la programación transnacional televisiva desde Estados Unidos y Latinoamérica.

La redefinición de lo que se entiende hoy por cultura participa directamente en este rejuego de bordes y fronteras. Se dice que la cultura se ha vuelto omnipresente en la era posmoderna, aunque no está claro si ello implica una diseminación o una disolución de las formas artísticas que la nutren. En cualquier caso, esa misma indeterminación asume la condición fronteriza de todo intelectual, ya que hacer crítica hoy en día implica permutar, transitar, o viajar entre espacios inciertos y a veces efímeros. La intelectualidad dedicada a la cultura actual surge precisamente de este impulso que tiende a formular nuevos métodos y teorías de estudios comparativos desde un enfoque multidisciplinario mucho más expansivo que lo permitido por la organización disciplinaria tradicional de occidente. Al conducir la teoría posmoderna hacia el ámbito de la diáspora intelectual del antiguo tercer mundo, se procura exacerbar la relación entre la especificidad (nacional, étnica, sexual) del intelectual, la condición huérfana y nómada de las teorías globales en sí, y la creciente formación de comunidades discursivas dentro de un ámbito académico también globalizado por la tecnología y los mercados. Se trata de una red de relaciones que el feminismo ha sabido internalizar desde hace tiempo, puesto que la mujer siempre ha tenido que negociar el espacio de sus instancias discursivas. Por otra parte, al aludir a la referencialidad implícita en todas las posiciones críticas, la mirada fronteriza también permite problematizar otras, entre ellas la bandera de la autoctonía nativista, puesto que la pertenencia al suelo nacional tampoco garantiza una relación desinteresada y exenta de mercados y valores, ni lo nacional responde a una definición unívoca, ni la cultura a una delimitación estrictamente nacional.

Los horizontes de la diáspora académica forman parte de una industria de discursos e imágenes de la cual ya no hay escape sino instancias y estrategias entre lectores, escritores y consumidores. Su inquietud principal ha sido la de abordar las colonias internas o el neocolonialismo modernizante con nuevas perspectivas desmitificadoras, y canalizar el 
montaje de nuevos objetos de estudio de la otredad, entre ellos la latinidad norteamericana, el feminismo, la subalternidad, u otras, a la par de una visión más multitemporal de la cultura global. Pero habría que observar también si esta óptica es capaz de problematizar suficientemente el triunfalismo posmoderno, si a partir de ella se posibilita una mirada más crítica de la cultura neoliberal, y si se concibe la cultura más allá del encierre epistemológico. Habría que estudiar estos y otros deslindes más cercanos al espacio vivencial latino en las Américas. ¿Cómo se producen y reproducen las diversas comunidades discursivas hoy en cada nación, o en cada región? ¿Qué tipos de diásporas y fronteras se manifiestan entre los márgenes de esas localidades? ¿Cómo trazan su cartografía de lo latino, lo norteamericano y lo latinoamericano? ¿Cómo entienden su relación con la influyente comunidad de intelectuales consagrados en el estudio de un solo país o una área geográfica, formación que corresponde a la estructura de estudios de área nutridos por la guerra fría, que hoy ya cede ante las pulsaciones globalizantes? Creo que estas dudas y preguntas permanecen sobre el tapete.

La demarcación de lo latino exige por lo tanto una mirada más detenida sobre el contexto de la confección del deseo que hoy se manifiesta a través de la producción televisiva e informática, la cual estrecha profundamente sus vínculos con la energía imaginativa de las artes y otros presupuestos performativos. Este aspecto, profundamente contradictorio, incorpora activamente el carácter vivencial de la globalización en el terreno de producción académica: las escuelas se vuelven agentes secundarios de escolarización; los medios masivos y la educación instrumental de las corporaciones instrumentalizan los imaginarios de los ciudadanos en tanto consumidores; la entrada a la clase media exige capital simbólico que no siempre se adquiere en la escuela; no hay canales o discursos establecidos para descifrar o interpretar críticamente la sociedad globalizada por su cuenta. Esta podría ser la frontera de mayor importancia para los estudios de la cultura transnacional, y también la menos atendida por los discursos establecidos de la deconstrucción. La producción de imágenes — televisión, video, anuncios, red informativa, arte performativo, y otras nuevas cotidianeidades masmediáticas - participa claramente en una relación distinta con el intelectual académico de letras, incluso el deconstructor. El espacio antes entendido por "la calle" irrumpe ahora con nueva fuerza y legitimidad, actúa como articulación que voltea la división entre la alta y baja cultura, sobre todo a través de la televisión. Se hace más difícil separar el corpus de textos canónicos de las experiencias de los consumidores. Se vuelve mucho más medible la recepción cultural a través de las estadísticas del consumo que gobiernan la producción, particularmente por medio de Internet. En suma, el espacio del investigador o intermediario se hace irremediablemente más público, y por ende más político, aún cuando estos inesperados retos provengan del estrato económico del propio capitalismo y no de su oposición, como antes se esperaba.

Es ya casi un lugar común decir que las crisis de identidades, la multitemporalidad, y el multiculturalismo se han hecho palpables en casi todas partes del mundo; así se confirma, más o menos, el lado celebratorio de la posmodernidad. Como reflexión histórica esta condición de incertidumbre global exige complicaciones ideológicas. Queda por articularse un discurso para el futuro específico de las sociedades que habitan la cotidianeidad desde modernidades truncas, fallidas, o en proceso de desarticulación. Gran parte de las Américas corresponde a ese espacio: sociedades sin discursos ni horizontes actuales, vacíos entre el 
neoliberalismo y el postsocialismo. Creo que la latinidad norteamericana provee un índice importante de esta problemática donde menos se esperaba. Nótese la vehemencia con que el conocido crítico norteamericano Harold Bloom recoge las velas del quiebre disciplinario desde la institucionalidad literaria: "Nada resulta tan esencial al canon occidental como sus principios de selectividad, que son elitistas sólo en la medida en que se fundan en criterios puramente artísticos...Uno sólo irrumpe en el canon por fuerza estética, que se compone primordialmente por la siguiente amalgama: dominio del lenguaje metafórico, originalidad, poder cognoscitivo, sabiduría y exuberancia en la dicción” (El canon 8).

Se puede compartir la importancia que Bloom le otorga a la gran literatura, y preguntar, también con Bloom, si los nuevos espacios del saber abandonan prematuramente valores estéticos aún necesarios para la era posmoderna. Pero se podría argüir que la nueva antología de formas culturales, la que llevan dentro los estudiantes y consumidores de hoy, contiene su propia exuberancia expresiva e idiomas metafóricos. Tómese como ejemplo el exceso visual de las imágenes en video, o la exuberancia oral de la música rap, o el impulso que invoca el movimiento corporal de la salsa. En cuanto a sabiduría y poder cognoscitivo, importa tomar en cuenta que son categorías peligrosas para el arte. Cuando se exige que el arte corresponda a un saber o un conocer establecido, se invoca una escala de valores que es prontamente reclamada por la filosofía, la historia y, por supuesto, la ideología. El lamento estético que hace Bloom en nombre de la literatura es más importante como síntoma de las contradicciones implícitas en la política cultural de la globalización. La consigna canónica del esteta norteamericano también implica un atrincheramiento ante los quiebres disciplinarios y la contracción del aparato humanístico universitario. Recoge, en gran medida, otro registro de los conflictos entre la clase cultural y la comercial que obtiene relevancia en la discusión de la latinidad norteamericana.

No debe olvidarse que la tradición de estudios literarios norteamericana ocupa un gran espacio institucional que cuenta con cientos de universidades estrechamente vinculadas a un complejo de bibliotecas y casas editoriales, al igual que divisiones disciplinarias muy costosas. La crisis sentida en la última década ha cerrado o consolidado muchos de estos espacios, entre ellos departamentos de estudios de lengua y literatura que antes eran imprescindibles para el estudio humanístico. Curiosamente, la lengua española siempre mantuvo un lugar de menor prestigio en esa jerarquía de valores europeos, pero hoy es la que más relieve cobra en tanto lengua americana, no sólo por los indiscutibles valores literarios latinoamericanos de los últimos cuarenta años, o por la importancia geopolítica de América Latina durante la Guerra Fría, sino porque es hablada (o al menos incorporada a la vivencia cotidiana) por más de 30 millones de latinos en Estados Unidos. Claro que hay otro aspecto importante: el mercado editorial en inglés también se ha expandido debido a la creciente presencia de autores latinos que escriben en inglés con un marco cultural distante del anglosajón. A ellos se añaden las voces asiáticas y caribeñas de procedencia inglesa y francesa. La relación entre lengua, literatura, y cultura nacional exige nuevos paradigmas.

El reto a los estudios literarios tradicionales es pues categórico, y con ello va la ansiedad en cuanto al futuro disciplinario académico, que a veces llega hasta el contexto más amplio de todas las humanidades y ciencias sociales. No debe olvidarse que, en general, las ciencias sociales norteamericanas, y en gran modo las latinoamericanas, han evitado hasta hace poco el duro cuestionamiento de los grandes epistemas modernos ocasionado por 
la economía neoliberal y la deconstrucción humanística. Pero quizá en ese desencuentro, entre los quiebres disciplinarios y las nuevas formas culturales, se produzcan posibilidades inéditas. El extrañamiento mutuo entre americanistas de acá y allá e intermedio, provocará dudas y debates a la hora de confeccionar proyectos de investigación; y si se dan nuevos puntos de encuentro, no serán suministrados exclusivamente a partir del antiguo academicismo literario, por los estudios de área, o desde la exclusiva especialidad nacionalista.

¿Cómo acoplar pues los anchos resquicios entre las disciplinas académicas y su objeto de estudio? Hay muchas respuestas posibles, pero se pueden atisbar al menos tres alternativas de valor general: 1) Hacer de la universidad un recinto de resistencia que rescate el orden disciplinario anterior a la dispersión posmoderna, 2) Sucumbir a la relativización de valores críticos y artísticos que promulga el mercado posmoderno, 3) Armar una nueva relación crítica entre el conocimiento académico y las diversas formas y mercados culturales. Bloom, al parecer, intenta reclamar la autoridad normativa del buen gusto. Pero esa sería una lectura demasiado sencilla de su propuesta. No se trata simplemente de restablecer el orden exclusivista del humanismo tradicional, sino de reordenar los estudios literarios montando un nuevo canon de literatura mundial capaz de incluir unos pocos autores no europeos orgánicamente traducibles y reconvertibles. Esto podría implicar la posibilidad de un corpus y una hermenéutica globalizante, es decir, una comunidad de lectores profesionales, bibliotecas y editoriales bien remuneradas, o al menos costeables. La literatura alcanzaría así otro grado de universalidad y prescindiría cada vez más de las exigencias de las culturas locales.

La producción de un canon de literatura mundial — con vocación occidental, y traducida a la lingua franca de la globalización, que sería el inglés - permitiría renovar la función de los estudios literarios, reafirmando al mismo tiempo el espacio institucional de tradiciones valiosas ante la dispersión masmediática de disciplinas académicas. No está claro, sin embargo, si se puede jerarquizar "lo literario" a partir de una sola lengua que operaría como moneda de cambio transnacional, ni tampoco es seguro que las presiones transformativas del capitalismo global puedan ser tan fácilmente disipadas en el terreno discursivo. La intención de Bloom se traiciona con la ambición de su propuesta. Quisiera preservar el espacio tradicional de la gran literatura con una apuesta que exige una relación muy contemporánea entre valor comercial, lenguaje de expresión y moneda de cambio estético.

Estas disyuntivas se pueden palpar con más claridad aún en la obra del pensador norteamericano Richard Rorty, quizá la figura más prominente de la filosofía neopragmática actual. Sus últimos libros y ensayos buscan definir más concretamente el enfrentamiento entre las teorías posmodernas, el viejo orden letrado, y la dispersión cultural globalizante. Reclama, primeramente, que la deconstrucción derridiana y la crítica de los metarrelatos de Foucault deben entenderse más como continuación que como ruptura de la tradición hermenéutica occidental, y que sólo tienen sentido en el ámbito de la literatura, la filosofía y las bellas artes. Es decir, que la crisis de valores sólo ocurre al llevar estas teorías al terreno de la cultura popular o la política, tomando demasiado en serio sus proyecciones liberadoras, como si de allí pudiera salir un nuevo sentido utópico o preservarse el radicalismo social de los metarrelatos modernos. De forma análoga a las teorías del fin de la historia y las ideologías de Francis Fukuyama, Rorty insisten que la posmodernidad no tiene que aspirar 
a nuevos horizontes, sino consolidar las comunidades que él llama “democracias burguesas posmodernas del Atlántico del Norte”, tomando en cuenta que sólo éstas se conforman al modelo posmoderno, puesto que han sido capaces de llevar la privacidad individual al grado más alto conocido en la historia, acomodando un margen inigualable de satisfacciones, opiniones, estilos de vida y medios de autogestión. El nuevo sujeto de estas comunidades, al igual que sus filósofos, participarían en un diálogo interno autosuficiente que ya no tiene que aspirar a una universalidad teórica, puesto que participan en una cultura nacional insuperable, y por ende, universal. Desde este horizonte, la crítica posmoderna sólo debiera remitir a ciertos ajustes inmanentes de tradiciones nacionales, un reconocimiento de que no hay un más allá que importe, fuera de la exploración reflexiva entre las democracias posmodernas. $^{2}$

Aunque se trate de una lectura muy sui generis, y hasta contradictoria, no ha de sorprender a nadie que Rorty proponga un encierre casi nacionalista para entender la posmodernidad filosófica, precisamente cuando ésta se manifiesta como fuerza de dispersión de valores del saber, es decir, como globalización. La creciente heterogeneidad nacional, cada vez más conflictiva, se filtra por las estructuras académicas de las letras y las ciencias sociales sin rumbo concreto, $y$ a veces contradictoriamente, ya sea reduciendo la fuerza de la crítica posmoderna a un discurso local, ya sea buscando una fusión renovadora del crisol de las razas entre la nueva multiculturalidad y el viejo monolingüismo. En todo caso, es en estos resquicios disciplinarios donde más se debate el impacto de la latinidad norteamericana. La dispersión del monolingüismo y el universalismo tradicionales ciñen tensiones inéditas. El inglés de la nación se mira en el espejo de los estudios literarios buscando una metáfora del capitalismo global: absorber todos los estímulos y transformarlos en nuevas monedas de cambio. El desafío a esa tradición viene ahora de dos pulsaciones internas estrechamente relacionadas: las migraciones que complican la identidad nacional como nunca antes, y la propia performance visual masmediática que ya produce su propia antología multicultural.

No hay duda de que las propuestas de Bloom y Rorty proveen un índice de las paradojas que hoy se observan en la cultura global, particularmente por el incierto futuro de las mitologías nacionales, particularmente las que sostienen una idea unívoca de la cultura nacional. Ello explica, aunque no justifique, la idea de reordenar las bases estéticas occidentales esquivando las exigencias discursivas de nuevos sujetos, entre ellos mujeres, minorías étnicas, gays, y sujetos no tan nuevos, como los trabajadores que ahora se sienten abandonados por el capitalismo transnacional. Estas páginas han buscado otras sendas, entre ellas la de actualizar un sentido más dinámico de la relación entre culturas y estéticas globales, y la de explorar el espacio del nuevo mercado de imágenes y ontologías que estimula contradictoriamente las ambiciones privadas de todos los sujetos, incluyendo los de menos recursos.

También debe observarse que el quiebre final del socialismo y el tercermundismo oficial encrespan aún más el turbio espacio conceptual posterior a 1989: si bien la promesa vanguardista de la posmodernidad occidental se trastorna con la globalización económica y las doctrinas neoliberales, es igualmente importante notar que el proyecto teleológico inspirado en la modernidad estatal del tercer mundo ha perdido más prestigio aún. Al mismo

${ }^{2}$ Ver el planteo de Christopher Norris, The Truth about Postmodernism. 
tiempo, el desarrollo de la televisión global, los pactos de libres mercados y la producción simbólica de los nuevos intelectuales empresariales cobran más importancia e intensidad, en tanto lógica cultural de esta economía. En ese respecto, la resistencia y el desencanto de toda una intelectualidad que antes se orientaba en torno a posiciones tajantes — capitalista/ socialista, nacional/exiliada, canónica/relativista - es comprensible pero insuficiente. A partir del 89, la vieja y nítida separación de planos estéticos, políticos y económicos cede ante las nuevas cartografías y los nuevos mercados de imágenes. Todo ello exige más bien un examen desafiante de ejes simultáneos —nación, género, confección ontológica, lengua, clase social, razas, entre otros—-, al igual que una valoración más amplia de la relación entre la palabra escrita y otras formas culturales.

Bibliografía

Bloom, Harold. El canon occidental. 2 2a ed. Barcelona: Anagrama, 1996.

García Canclini, Néstor. Consumidores y ciudadanos. México: Grijaldo, 1995.

Norris, Christopher. The Truth about Postmodernism. Cambridge: Blackwell Publishers, 1993.

Pérez, Lisandro. “De Nueva York a Miami”. Encuentro 15 (1999-2000).

Pérez Firmat, Gustavo. Life on the Hyphen: The Cuban-American Way. Austin: University of Texas Press, 1994.

Rorty, Richard. Objectivity, Relativism, and Truth. Cambridge: Cambridge University Press, 1991. 